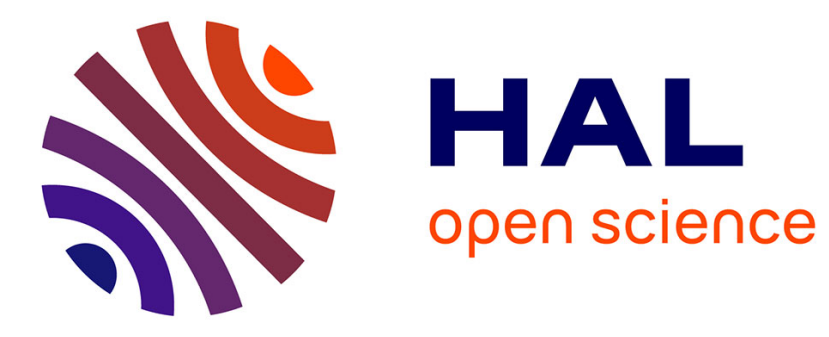

\title{
Phoretic mites (Acari: Chaetodactylidae) associated with the solitary bee Tetrapedia diversipes (Apidae: Tetrapediini)
}

\author{
Guaraci Cordeiro, Mariana Taniguchi, Carlos Flechtmann, Isabel
}

Alves-Dos-Santos

\section{To cite this version:}

Guaraci Cordeiro, Mariana Taniguchi, Carlos Flechtmann, Isabel Alves-Dos-Santos. Phoretic mites (Acari: Chaetodactylidae) associated with the solitary bee Tetrapedia diversipes (Apidae: Tetrapediini). Apidologie, 2011, 42 (2), pp.128-139. 10.1051/apido/2010044 . hal-01003578

\section{HAL Id: hal-01003578 https://hal.science/hal-01003578}

Submitted on 1 Jan 2011

HAL is a multi-disciplinary open access archive for the deposit and dissemination of scientific research documents, whether they are published or not. The documents may come from teaching and research institutions in France or abroad, or from public or private research centers.
L'archive ouverte pluridisciplinaire HAL, est destinée au dépôt et à la diffusion de documents scientifiques de niveau recherche, publiés ou non, émanant des établissements d'enseignement et de recherche français ou étrangers, des laboratoires publics ou privés. 


\title{
Phoretic mites (Acari: Chaetodactylidae) associated with the solitary bee Tetrapedia diversipes (Apidae: Tetrapediini)*
}

\author{
Guaraci Duran CoRdeIRO ${ }^{1}$, Mariana TANIGUCHI ${ }^{1}$, Carlos Holger Wenzel \\ FLECHTMANN $^{2}$, Isabel ALVES-DOS-SANTOS ${ }^{3}$
}

\footnotetext{
${ }^{1}$ Departamento de Biologia, Faculdade de Filosofia, Ciências e Letras de Ribeirão Preto, Universidade de São Paulo (USP), Av. Bandeirantes, 3900, Bloco 2, 14040-901, Ribeirão Preto, SP, Brasil

${ }^{2}$ Departamento de Entomologia, Fitopatologia e Zoologia Agrícola, Escola Superior de Agricultura Luiz de Queiroz (ESALQ), Universidade de São Paulo (USP), Caixa postal 9, 13418-900, Piracicaba, SP, Brasil ${ }^{3}$ Laboratório de Abelhas, Departamento de Ecologia, Instituto de Biociências, Universidade de São Paulo (USP), Rua do Matão 321, trav 14. Cidade Universitária, 05508-900 São Paulo, SP, Brasil
}

Received 7 October 2009 - Revised 25 March 2010 - Accepted 26 March 2010

\begin{abstract}
Solitary bees of the genus Tetrapedia have a specific association with mites of the genus Roubikia (Chaetodactylidae). These mites are frequently found attached to active Tetrapedia bees. We quantified the number of mites on individuals of Tetrapedia diversipes Klug and examined the interaction between these species. Nests of $T$. diversipes were obtained from trap-nests placed in four localities in São Paulo, Brazil. The study lasted from March 2007 to February 2009. Out of a total of 650 nests with emergences, 118 were infested with mites (Roubikia sp.). From these nests, 176 individuals of $T$. diversipes emerged with mites on their bodies. Additionally, six individuals of Coelioxoides waltheriae, the specific kleptoparasitic bee to $T$. diversipes, emerged. Mites were attached mainly to the mesosoma. All nests infected with mites did not presented mortality of the immature. The mortality rate of nests was inversely related to the level of mite infestation, suggesting a mutualistic interaction in which mites may remove fungi from the nests, while the bees would provide the mites with transport, dispersal, and shelter.
\end{abstract}

solitary bee / phoresy / trap-nest / Atlantic Forest / symbiosis

\section{INTRODUCTION}

Mites and bees have co-existed since the Cretaceous, and there is evidence of a close relationship between some taxa, probably resulting from a co-evolutionary processes (Klimov et al., 2007a). Most mite lineages associated with bees use species of Apidae and Megachilidae as hosts (Eickwort, 1994; Klimov et al., 2007a). These mites belong to the family Chaetodactylidae (Acari: Astigmata). Associations with basal lineages of Megachilidae

Corresponding author: I. Alves-dos-Santos, isabelha@usp.br

* Manuscript editor: Stan Schneider
(Lithurgini) and Apidae (Xylocopini) suggest that chaetodactylids may have established themselves in the Lower Cretaceous, when these two bee families became separated (Engel, 2001). Another hypothesis is that the mites arose in a later period, during the Eocene, when many exchanges among hosts would have occurred simultaneously with the dispersal of bees through the continents (Klimov and O'Connor, 2007).

Chaetodactylidae comprises over 200 described species within five genera and distributed worldwide, except for the poles (Klimov and O'Connor, 2008). The active initial phases of the mites (larva and nymph) have been described for 85 species. During 
these phases, mites live within the bee nests and feed on materials found in the brood cells, and may be mutualists (consuming nest wastes), parasitoids (killing the egg or the larva), commensals or parasites (consuming the larval food and so hindering the development of the larva) (Krombein, 1962; Roubik, 1987; Qu et al., 2002). Most Chaetodactylidae species are found in association with bees in the phases of deutonymph or phoretic hypopus, frequently positioned on the acarinarium (Fain, 1981). In this dispersal stage, the mite stops feeding and becomes inactive; it is transported by the host to the next site where a new cycle begins (Baker et al., 1987). The hypopi have a morphology fully adapted to this life phase: they have no mouthparts or digestive tract, a highly sclerotized carapace, which prevents dehydration, robust pretarsal claws, and caudoventral suckers for attaching to the host (Houck and O'Connor, 1991). In most cases, a certain synchronism between the life cycles of both associates occurs (Klimov and O'Connor, 2007).

Some bee species exhibit specialized regions on the body called acarinaria where mites are frequently lodged (O'Connor and Klompen, 1999). Acarinaria are small cavities, sometimes covered with setae, which facilitate the attachment of mites to the bee's body and provide them protection during transport. These structures occur in many families of aculeate hymenopterans (Eickwort, 1994; O’Connor and Klompen, 1999) and are evidence for the strong reciprocity that those interactions have been present through evolutionary time. However, not all bees with associated mites exhibit developed acarinaria, and the mites can, therefore, be distributed randomly on the host body (Klimov et al., 2007b). Among bees of the family Apidae, acarinaria are present in species of Xylocopa, Ceratina, and Tetrapedia (Klimov and O'Connor, 2007). However, these features not always result from mutualistic associations (Klimov et al., 2007b).

Despite the specificities within associations, host changes may occur. In some cases, they occur by mistake. For instance, a mite may remain on flowers (ex. Sennertia) and attach to different bees, or a mite that blends in the sand and soil particles may attach to certain bees that collect this material (Roubik, 1987; Vicidomini, 1996). There are frequent changes between relatively close taxa within the same genus (Klimov et al., 2007b). Approximately 170 Sennertia species are associated with 469 species of Xylocopa (Michener, 2000; Klimov and O'Connor, 2007).

Among the solitary bees, the genus Tetrapedia (Apidae, Tetrapediini), a group of oilcollecting bees, was reported to be in specific association with mites of the genus Roubikia (Roubik, 1987; Klimov and O'Connor, 2007; Klimov et al., 2007a, b). The mites also lodge on Coelioxoides (Apidae: Tetrapediini), their specific kleptoparasitic species (Klimov et al., 2007a). It was known that the interaction between Roubikia and Tetrapedia is commensalistic: the mites feed on larval food and on nest materials without causing any harm to the immature (Klimov et al., 2007b). The association is restricted to the Neotropical region, which is an area of occurrence for both groups.

Alves-dos-Santos et al. (2002) and Camillo (2005) studied the nesting biology and the nest architecture of Tetrapedia diversipes. This species has a bivoltine cycle: the first generation is active in the spring, whereas the second is active in the summer. The females nest on wood substrate and frequently use preexisting cavities in tree bark made by beetles; in such cases, they may be captured in trapnests (Garófalo et al., 2004). Old nests are frequently re-used. The oil collected by the females is used for nest construction, compacted with sand particles, and mixed together with pollen for larval food. The larvae of Tetrapedia develop in cells and do not spin cocoons. Coelioxoides waltheriae Ducke is the specific kleptoparasitic species of $T$. diversipes.

We suppose that if the relationship of Roubikia mites with $T$. diversipes is mutualistic, than a lower mortality rate would be found when the mites are present. Therefore, the objectives of the present study were to verify the infestation by mites of the genus Roubikia both in nests and on emerging individuals of the solitary bee Tetrapedia diversipes and to study the interaction between them. 


\section{MATERIAL AND METHODS}

We obtained nests of Tetrapedia diversipes by setting up trap-nests. This method is widespread for the capture of solitary bees and consists of offering artificial cavities through cardboard tubes lodged in perforated wooden blocks or bamboo tubes (Camillo et al., 1995; Garófalo et al., 2004).

The present study was carried out for two years, between March 2007 and February 2009, in four areas within the dense rainforest domain of the Atlantic Forest of the state of São Paulo, Brazil: Parque Estadual de Ilhabela $\left(23^{\circ} 45^{\prime} \mathrm{S}-45^{\circ} 27^{\prime} \mathrm{W}\right.$, altitude: 0-1.378 m, São Sebastião municipality), Parque Estadual da Serra da Cantareira (23 $30^{\circ}$ 'S46 45'W, altitude: 950-1.074 m, São Paulo municipality), Parque das Neblinas $\left(23^{\circ} 45^{\prime} \mathrm{S}-46^{\circ} 09^{\prime} \mathrm{W}\right.$, altitude: $700-1.100 \mathrm{~m}$, Mogi das Cruzes municipality), and Estação Biológica de Boracéia (23 38'S$45^{\circ} 52^{\prime} \mathrm{W}$, altitude: $750-900 \mathrm{~m}$, Salesópolis municipality). Additional nest material came from the Bee Laboratory at the campus of the University of São Paulo - USP $\left(23^{\circ} 33^{\prime}\right.$ S $-46^{\circ} 43^{\prime} \mathrm{W}$, São Paulo municipality). In Parque Estadual da Serra da Cantareira the sampling was carried out within a year, between March 2007 and February 2008.

We inspected trap-nests monthly. Established nests were removed from the field and taken to the laboratory, where they remained lodged in individual test tubes capped with a cork. The emerging individuals were killed with ethyl acetate and prepared for mounting in an entomological collection. Finally, we opened the nests in order to study their internal contents and mortality record. We analyzed thoroughly all emerging individuals under a stereomicroscope for the selection of bees with mites on the body. We counted the mites on bees according to the place of attachment to the bee's body.

We separated three infested nests from the University's campus after the emergence of the bees in order to study their internal content. The nests were opened and placed in Petri dishes and kept in a dark environment. We followed the mites' eggs until they hatched.

Flowers of sweet basil (Ocimum basilicum, Lamiaceae) from the garden at the Bee Laboratory at the University, which are frequently visited by Tetrapedia diversipes, were collected and examined to check for the presence of mites. Bees were also collected on the flowers to check for the presence of mites and the place of attachment to the body of bees in activity.

We recorded images of bees with mites using a camera attached to a stereomicroscope (Leica -
MZ16, software IM50). For further details, images were made with a scanning electron microscope (SEM) in the laboratory NAP/MEPA at ESALQ USP Campus Piracicaba. We glued dried specimens in stubs with a double-sided tape at the desired position and subjected them to gold metallization.

We identified the hypopi based on the study and identification keys by O'Connor (1993b) and Klimov et al. (2007b). All examined samples were deposited in the Entomological Collection Paulo Nogueira Neto (CEPANN) of the Biosciences Institute of University of São Paulo.

We tested whether the sex ratio deviated from the expected proportion of 1:1 using a Chi-square test. The effect of infestation on survival and the difference of infestation between sexes were tested with a t-test. We correlated the rate of infested nests by mites with the mortality rate of nests in the four areas to check the relationship between the two variables. To test the effect of seasonality in the infested nests, we used the Chi-square test. Significance was determined at the 0.05 level.

\section{RESULTS}

We obtained 913 nests of Tetrapedia diversipes from the traps disposed in the four areas. Among them, occupants emerged from 650 nests, from which $118(18.1 \%)$ were infected with mites (Tab. I). In the remaining 263 nests, we recorded the total mortality of the occupants at different development phases (larva, pupa and pre-emergence adult). The main diagnosed cause for immature mortality was the infestation by fungi.

From the nests infested by mites, 176 individuals of $T$. diversipes emerged (142 males and 34 females) bearing mites on their bodies (Figs. 1A, B), which correspond to $81 \%$ of the bees in these nests. In $91 \%$ of the infested nests, all individuals carried mites. The infestation rate of mites from the total of emerging individuals was $14.3 \%$ (Tab. II).

Six individuals of Coelioxoides waltheriae, the specific kleptoparasitic species of $T$. diversipes, also emerged ith attached mites (Figs. 1C, D), one from each infested nest. Individuals of the parasitic species Anthrax (Diptera) that emerged from infested nests did not have mites attached to their body. 


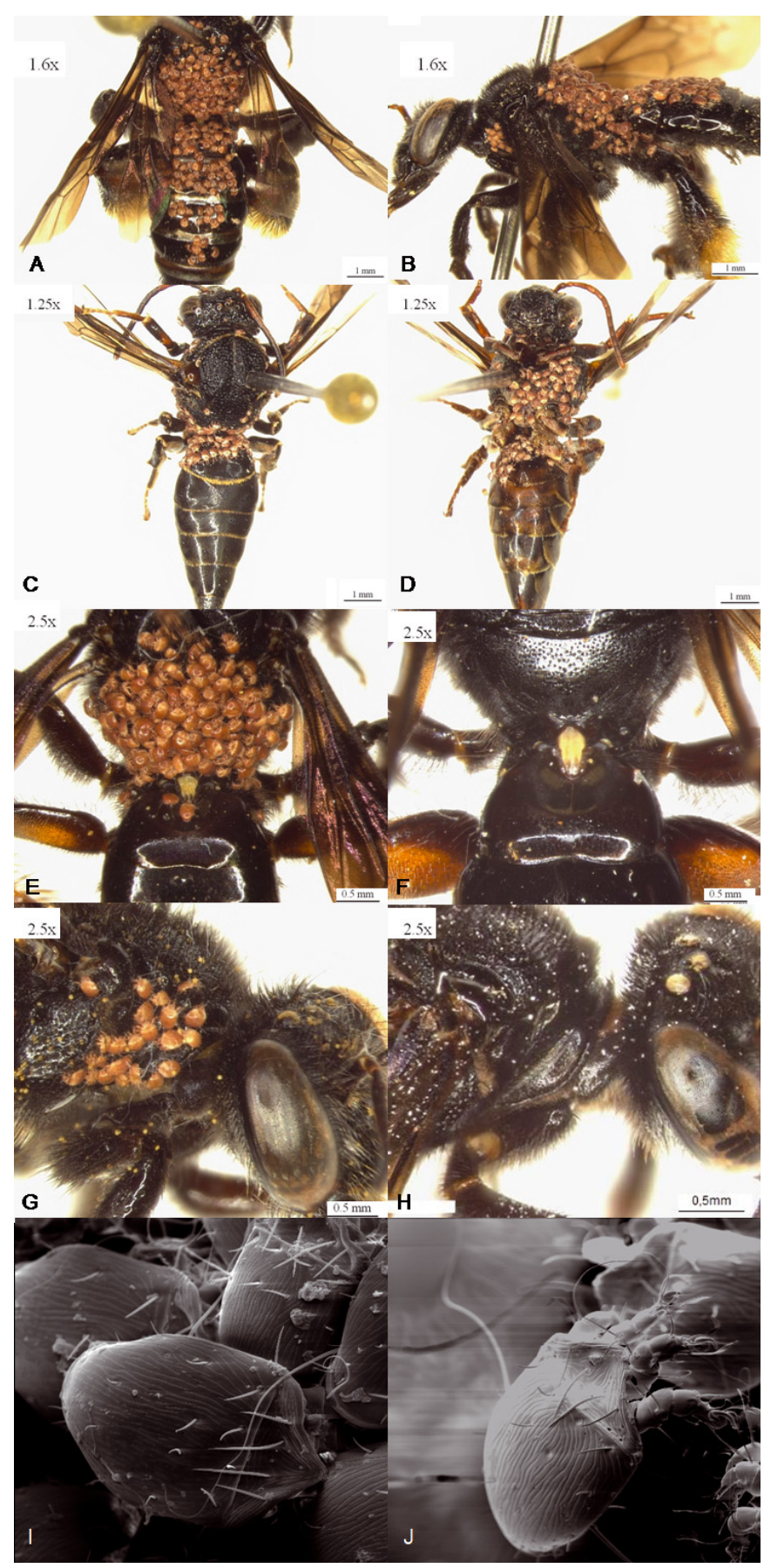

Figure 1. A and B: Male of Tetrapedia diversipes with mites attached in dorsal view and in lateral view. C and D: Coelioxoides waltheriae with mites attached in dorsal view and in ventral view. E and F: view of the parts with higher concentration of mites. Region of the propodeum and scutellum with and without mites. $\mathrm{G}$ and $\mathrm{H}$ : region of the pronotum with and without mites. I and $\mathrm{J}$ : images in SEM of individuals of Roubikia sp on the mesosoma. 
Table I. Nests founded by Tetrapedia diversipes in the four study areas from March 2007 to February 2009, and mite infestation in the nests with emergence.

\begin{tabular}{cccccc}
\hline Study areas & $\begin{array}{c}\text { Founded } \\
\text { nests }\end{array}$ & $\begin{array}{c}\text { Nests with } \\
\text { total mortality }\end{array}$ & $\begin{array}{c}\text { Nests with } \\
\text { emergence }\end{array}$ & $\begin{array}{c}\text { Nests infested } \\
\text { with mites }\end{array}$ & $\begin{array}{c}\text { \% of nests } \\
\text { infested } \\
\text { with mites }\end{array}$ \\
\hline Ilhabela & 501 & 141 & 360 & 76 & 21.1 \\
Boracéia & 228 & 50 & 178 & 36 & 20.2 \\
Pque. das Neblinas & 51 & 17 & 34 & 4 & 11.8 \\
Cantareira* & 133 & 55 & 78 & 2 & 2.6 \\
\hline Total & 913 & 263 & 650 & 118 & 18.1 \\
\hline
\end{tabular}

* In this locality the sampling took only one year.

Table II. Emerging individuals and individuals of Tetrapedia diversipes with mites in the four study areas from March 2007 to February 2009.

\begin{tabular}{cccccccc}
\hline Study areas & $\begin{array}{c}\text { Emerging } \\
\text { individuals }\end{array}$ & O" & ᄋ & $\begin{array}{c}\text { Individuals } \\
\text { with mites }\end{array}$ & $\begin{array}{c}\text { \% ind. with } \\
\text { mites }\end{array}$ & $\begin{array}{c}\text { O" with } \\
\text { mites }\end{array}$ & $\begin{array}{c}\text { \% with } \\
\text { mites }\end{array}$ \\
\hline Ilhabela & 650 & 456 & 194 & 97 & 14,9 & 85 & 12 \\
Boracéia & 353 & 179 & 174 & 64 & 18,1 & 42 & 22 \\
Pque. das Neblinas & 66 & 37 & 29 & 9 & 13,6 & 9 & 0 \\
Cantareira* & 159 & 67 & 92 & 6 & 3.8 & 6 & 0 \\
\hline Total & 1228 & 739 & 489 & 176 & 14.3 & 142 & 34 \\
\hline
\end{tabular}

* In this locality the sampling took only one year.

In the areas of Ilhabela and Boracéia the occurrence of nests with mites was higher than in Parque das Neblinas and Cantareira (Tab. I). The infestation rate of individuals in Cantareira was the lowest (Tab. II).

The infestation of $T$. diversipes was higher in males in all localities; however, this trend was not significant $(\mathrm{t}=0.369, \mathrm{df}=122, P=$ 0.71) (Tab. II). In Ilhabela, this pattern would be expected since the sex ratio in this locality is clearly biased towards males $\left(\chi^{2}=105.606\right.$, $\left.P=8.99 \times 10^{-25}\right)$. However, in the localities were the sex ratio was not significantly biased (Boracéia $\chi^{2}=0.0708, P=0.79$ and Neblinas $\left.\chi^{2}=0.969, P=0.325\right)$, or even where it was biased towards females (Cantareira $\chi^{2}=3.93$, $P=0.04)$, the proportion of infected males was still higher.

Throughout the studied period the highest infestation index of mites in nests coincided with the highest nesting rate, which was spring and summer (mainly November 2007 and February 2008); peaks probably correspond to the two annual generations of $T$. $d i$ versipes (Fig. 2). The number of nests with mites shows high seasonality $\left(\chi^{2}=421.9, P=\right.$ $0.00001)$. Likewise, the proportion of emerging individuals with mites was higher during those seasons (Fig. 3).

There was an average of $77.8 \pm 69.10$ mites per individual $(n=97)$ bee. However, we observed specimens carrying a maximum of 385 mites and others with only two individuals (Tab. III). The favorite area for mite attachment was the dorsal mesosoma, mainly on the scutellum, propodeum and pronotum (Figs. 1A, E, 4). However, we also found mites attached to other parts of the bees' body, such as the mesepisternum, the metasoma (terga and sterna) and the legs. Figures 1I, J show the hypopus of Roubikia in detail. In Coelioxoides waltheriae, the main area of attachment also corresponds to the region around the petiole (scutellum, propodeum and abdominal tergum) as well as the ventral mesosoma (Figs. 1C, D).

The mortality in nests showed a clear trend of a negative correlation with the infestation by Roubikia (Tab. I, Fig. 5). In all infested nests 


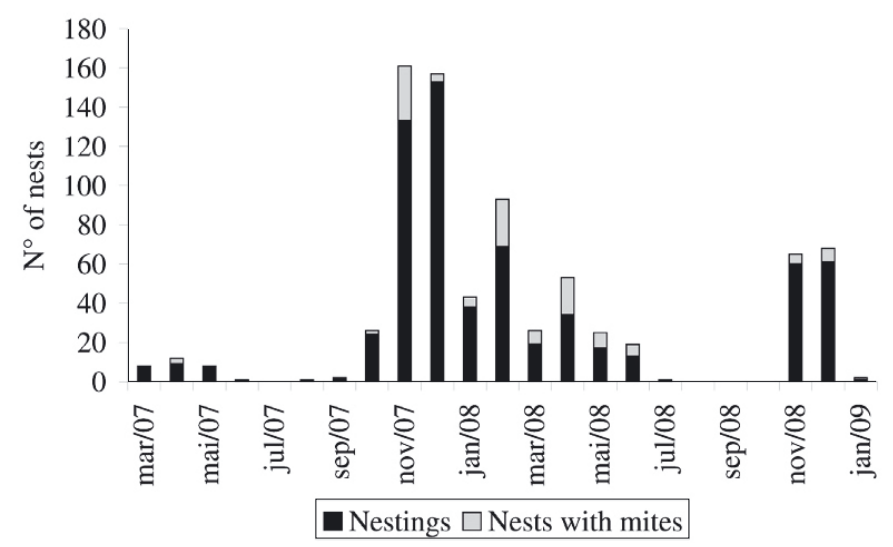

Figure 2. Nestings of Tetrapedia diversipes and nests with mites between March 2007 and February 2009 in the four study areas.

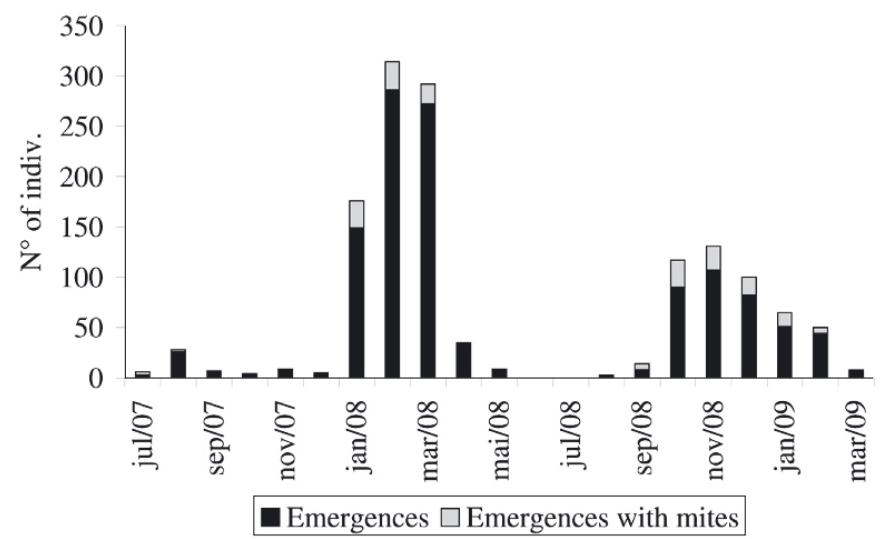

Figure 3. Emerging individuals and individuals of Tetrapedia diversipes with mites between March 2007 and February 2009.

Table III. Number of mites on individuals of Tetrapedia diversipes in the four study areas from March 2007 to February 2009.

\begin{tabular}{ccc}
\hline Study areas & $\begin{array}{c}\text { Mites per individual } \\
\text { average } \pm \text { std. dev. }(\text { min-max })\end{array}$ & $\begin{array}{c}\mathrm{N}^{\circ} \text { individuals examined } \\
(\mathrm{N})\end{array}$ \\
\hline Ilhabela & $47.4 \pm 70.25(2-385)$ & 53 \\
Boracéia & $132.3 \pm 58.36(5-270)$ & 27 \\
Pque. das Neblinas & $98.7 \pm 72.58(15-177)$ & 9 \\
Cantareira* & $72.6 \pm 64.14(22-234)$ & 8 \\
\hline Total & $77.8 \pm 69.10(2-385)$ & 97 \\
\hline
\end{tabular}

* In this locality the sampling took only one year. 


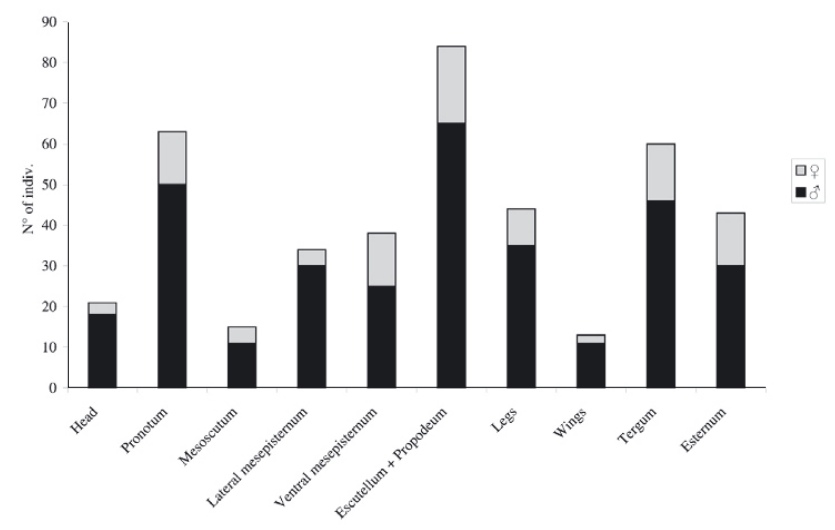

Figure 4. Number of male and female individuals of Tetrapedia diversipes examined $(n=97)$ with mites attached to different parts of the body.

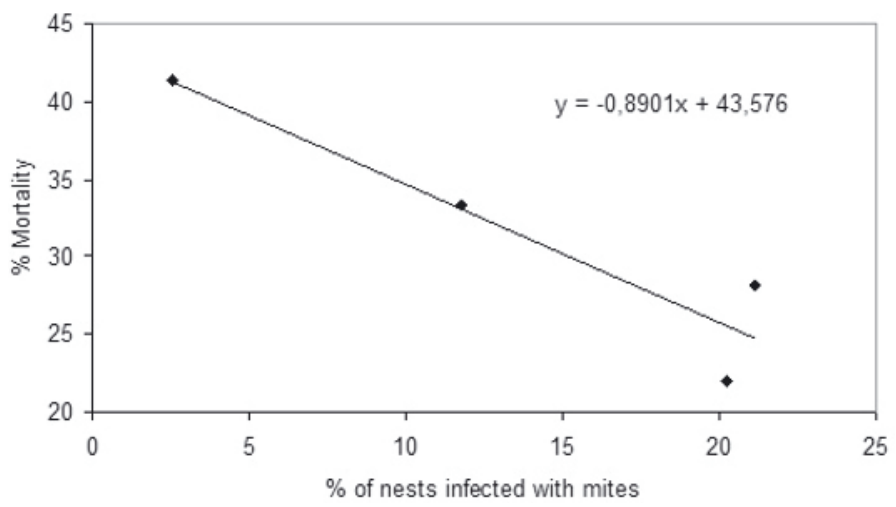

Figure 5. Relationship between total mortality in the nests of Tetrapedia diversipes and the percentage of mite infestation in the nests.

we did not record mortality, that is to say, the mites did not caused the death of individuals of T. diversipes. On the other hand, in uninfested nests, the mortality was about $15 \%$. This positive effect of infestation in the nests of $T$. $d i$ versipes with mites was significant $(\mathrm{t}=5.03$; df $=644 ; P<0.0001)$.

On the examined sweet basil flowers we found no mites; however, some females collected while visiting the flowers had mites attached to their bodies, mainly on the sides of the mesepisternum and some on the terga.

In the infested nests kept in Petri dishes, we observed several development phases of mites. Larvae and nymphs were observed every day moving around and among a pollen mass mixture with many exuviae, sand particles and feces of the host larvae inside the nest. Only a few hypopi were observed. We detected the presence of eggs from the first to the sixth day, and we observed a higher amount during the first three days. The eggs were tiny (about $0.1 \mathrm{~mm}$ ), elliptical and with a white-ish-translucent appearance when first laid; from the second day on, they exhibited an opaque color and a granular texture. From the third day on, some larvae started emerging.

\section{DISCUSSION}

Previous studies carried out on the associations between Roubikia mites and Tetrapedia 
bees (Baker et al., 1987; Roubik, 1987) showed that this is a case of commensalism. Mites apparently ingest wastes of larval food and nest materials without causing any harm to the immatures (Klimov et al., 2007a). Roubik (1987) proposed that the mites may also consume, in addition to the pollen, the flower oils present in the stock. The presence of a large amount of nymphs moving about the pollen mass in the nests opened for observation suggests that these nymphs may be feeding on wastes of the food previously consumed by bee larvae. Another evidence for this hypothesis is the presence of many exuviae with the pollen mass. Additionally other materials in the nests could also be consumed, such as larval feces, which were loose inside the cells, parts of exuviae of the bee larvae, and developing fungi.

Our results showed that the mortality in nests has a tendency of a negative correlation with the infestation by Roubikia (Fig. 5). In infested nests, no fungus was found and there was no mortality, suggesting that bees benefit from the presence of mites. Flechtmann and Camargo (1974) observed a mutualistic relationship of Neotydeolus mites (Tydeidae) in colonies of Scaptotrigona postica (Apidae), where the proliferation of fungi caused the death of brood. After the introduction of mites in the colonies, the propagation of fungi decreased rapidly, likely reducing death in the brood comb. Furthermore, O'Connor (1979) recorded fungivorous ancestors for mites of Astigmata. Recently, Biani et al. (2009) showed the mutualistic role of Laelaspoides mites (Laelapidae) in nests of Megalopta (Halictidae), where the mites eliminate the fungi that proliferate in nests.

Studies with solitary bees demonstrate the presence of fungi in the nests as the main cause of death (Morato, 2001; Camarotti-deLima and Martins, 2005). Although T. diversipes is a widespread species, the studied nests are from areas of Atlantic Forest with high rainfall rates, in particular during the summer, which most likely contributes to the proliferation of fungi. Possibly, Roubikia mites are eliminating fungi in $T$. diversipes nests since no bee died in the infested nests.
Studies carried out with species of Chaetodactylus (Chaetodactylidae) in Osmia cornifrons (Megachilidae) reported that the type of interaction may vary with the density of mites; in small quantities, the interaction is commensal, whereas in large quantities (>50 mites per cell), it becomes negative (Qu et al., 2002). This pattern is frequently observed in social bees (ex. Varroa in Apis mellifera), on which the high infestation rate in brood combs may lead to the collapse of the colony (Oldroyd, 1999; Menezes et al., 2009). In our study, even the bees that carried over 300 mites on their body emerged, i.e., even in large quantities the mites did not represent a death risk for $T$. diversipes individuals.

The parts of the body of $T$. diversipes with the highest concentration of mites (pronotum, scutellum and propodeum) are not characterized as acarinaria but as mesosoma depressions (Figs. 1E-H); here, the mites remain less exposed and less vulnerable during the transport. The attachment to other parts of the body, such as the spaces between the terga, the ventral region between the coxae or the sternum setae, probably occur for the same reason. In the observed bees, this generalized distribution occurred in individuals with a high amount of mites on the mesosoma, and the mites probably spread due to the intense agglomeration. Additionally, probably those regions of the body are difficult to reach during self-grooming. According to Krombein (1962), the mites of Chaetodactylidae may attach to the body of bees with claws or suckers that are ventrally located. In $T$. diversipes, in the mesosoma depressions lacking many setae (pronotum, scutellum, propodeum, terga and ventral mesepisternum), the mites should attach mainly with suckers; and in the regions full of setae (sterna, lateral mesepisternum and legs), they should attach with claws. Klimov et al. (2007a) observed in Peru an incipient acarinarium in a species of Tetrapedia located in the lowest part of the first metasomal tergum infested with mites of Roubikia latebrosa. However, they did not find this structure in any other species of Tetrapedia examined in the study.

We observed all the development phases of the mite-eggs, larvae, and nymphs, including 
some hypopi - simultaneously within the nests, where the bees had already emerged. Trouessart (1904) observed the occurrence of two types of hypopi in Chaetodactylus osmiae, a species associated with Osmia cornuta (Apidae): a phoretic form and an encysted one (Fain, 1966). According to the previous author, the phoretic form has a dispersal function, whereas the encysted form, present in higher numbers, remains in the nest in a quiescent state. The hypopi observed in the nests of $T$. diversipes are probably encysted, waiting for another host female, in case the nest is re-used. This strategy is adopted by several mite species (Krombein, 1962). While environmental conditions are favorable and there is food enough in the nest, the mites remain there to develope and reproduce. The transformation of protonymphs into hypopi occurs in different ways among mite species, but it usually occurs due to limiting factors such as lack of food, change in environmental conditions (extreme temperatures or low humidity), or it is activated according to the maturation of the host into adults. This synchrony is possibly caused by chemical substances (secretions and hormones) released by the host and detected by mites (Houck and O'Connor, 1991). The mites of Roubikia observed in the present study attach themselves only to bees, both the hosts ( $T$. diversipes) and the kleptoparasites (C. waltheriae), and not to parasitic dipterans (Anthrax), possibly due to chemical differences detected by mites too.

The hypopus phase is characterized by extreme resistance, and it may take days, weeks and even months (Houck and O'Connor, 1991). Schwarz and Huck (1997) recorded some mite species in which the hypopus remained for about $24 \mathrm{~h}$ on flowers, waiting for Bombus bees (Hymenoptera: Apidae) to disperse it among nests. We found that both routes of development may occur in Roubikia. The mites continue the cycle while there is food available and may infest the next brood in case of reutilization of the nest, and others turn into hypopi and ascend the bee about to emerge or remain encysted in the nest. Unlike Trouessart (1904), it was observed a higher amount of phoretic hypopi in relation to encysted ones.
In accordance with studies on other mites of Chaetodactylidae (Krombein, 1962; Park et al., 2009), the dispersal of the hypopi attached to the female host occurs when it provides the cells with the collected material (pollen, nectar or oil). The hypopi then step down to the new nest, undergo a molt to the adult stage and reproduce, starting the new generation (Qu et al., 2002). Females of Tetrapedia that were visiting sweet basil flowers (Ocimum basilicum) exhibited mites attached mainly to the sides of the mesepisternum, and some attached to the terga, differently from newly emerged bees that had mites dorsally concentrated, on the scutellum and propodeum. This distribution corroborates the dispersal behavior of the hypopi previously mentioned: since the females are building nests, the mites could be already positioned to descend to the nest. Another possibility would be that they concentrate on these parts to descend to flowers, or because they had shifted from flowers to bees, corroborating the hypothesis of the dispersal through flowers. However, we must keep in mind that the flowers visited by $T$. diversipes in the garden of the University were examined, and mites were not detected.

Furthermore, we must take into account that the infestation rate was higher in males of $T$. diversipes in all localities, even when there was a bias in the sex ratio towards females (Cantareira). In this case, a possible strategy could be the contamination or dispersal among the same nests. The nests of $T$. diversipes captured in trap-nests are clustered, located a few centimeters apart from each other. The most external cells are usually constructed for males (Alves dos Santos et al., 2002). Krombein (1962) also recorded higher infestation by Chaetodactylus krombeini in males of Osmia lignaria (Megachilidae). For the mites, the infestation of male bees may represent a broader range of dispersal, since they can fly longer distances searching for females. Regardless, the mechanisms of the mites dispersal remain unclear. According to Park et al. (2009) the mites carried by males would be impaired unless they were transferred to new females during the copula. Further studies are necessary to investigate how Roubikia mites disperse and if 
and how they provide a mutualistic benefit to Tetrapedia bees.

\section{ACKNOWLEDGEMENTS}

We would like to dedicate this paper to our professor, colleague and friend Prof. J.M.F. Camargo in admiration to his work and dedication to the Brazilian native bees. We are grateful to the Laboratory of Images NAP/MEPA of Escola Superior de Agricultura Luiz de Queiroz (ESALQ - USP), for helping with the images in SEM; Heber Couto, responsible for the collecting and supervision of the trap-nests in Parque Estadual da Serra da Cantareira; Roberto M. Shimizu (IBUSP) and Eduardo Pinto (FFCLRPUSP) for helping with data analysis; Solange Augusto (Univ. Fed. Uberlândia), Evandro Camillo (Univ. São Paulo) and the two anonymous referees for their pertinent suggestions; Margaret Couvillon and Raoni Cordeiro for revising the manuscript; and to FAPESP for the financial support (processes: 07/51911-2; 04/00274-4; 04/15801-0).

Acariens phorétiques (Acari : Chaetodactylidae) associés à l'abeille solitaire Tetrapedia diversipes (Apidae : Tetrapediini).

\begin{abstract}
Abeille solitaire / phorésie / nid-piège / Forêt atlantique / symbiose / Brésil / Roubikia / Coelioxoides
\end{abstract}

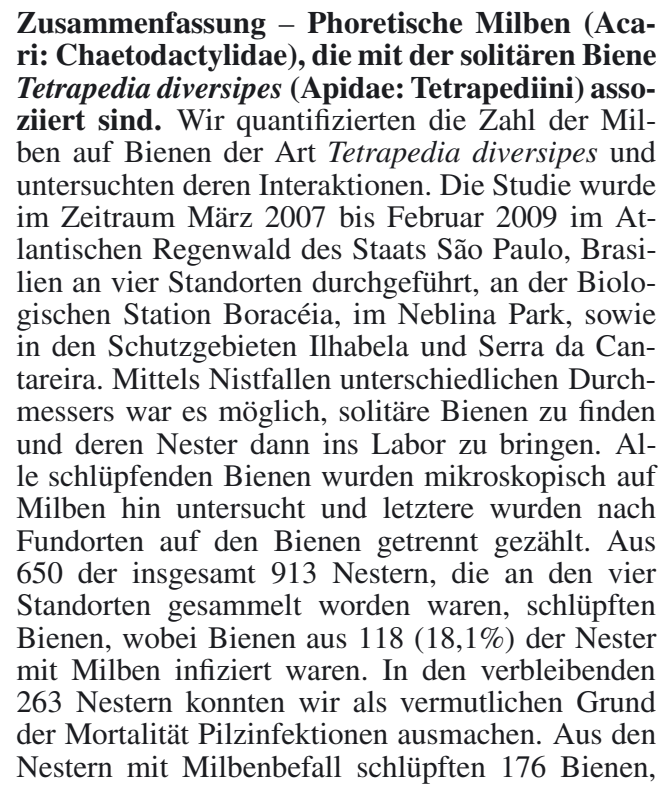

die Milben an ihrem Körper trugen, was $81 \%$ der Bienen aus diesen Nestern entspricht. Im Bezug auf die Gesamtzahl der schlüpfenden Bienen lag der Milbenbefall bei 14,3\%. Darunter fanden wir auch sechs Individuen der Art Coelioxoides waltheriae, eines spezifischen Kleptoparasiten von $T$. diversipes, die ebenfalls mit Milbenbesatz schlüpften. An den Standorten Ilhabela und Boracéia fanden wir eine höhere Zahl an Nestern mit Milbenbefall als in den Parks Neblina und Cantareira. Im Mittel fanden wir 77,8 \pm 69,10 Milben pro Biene $(\mathrm{n}=97)$ und zwar bevorzugt auf der dorsalen Region des Mesosoma-Segments. Obwohl der Körper von $T$. diversipes zwar keine sogenannten Acarinaria-Regionen aufweist, stellen die Eindellungen des Mesosomas doch Orte dar, and denen die Milben weniger exponiert und damit während des Transports besser geschützt sind. Frühere Studien über die Assoziation von Roubikia Milben mit Tetrapedia Bienen hatten angedeutet, dass es sich hierbei um Kommensalismus handelt. In unserer Studie zeigten jedoch die Mortaliätsraten der Bienen in den Nestern eine negative Korrelation mit dem Milbenbefall, was darauf hinweist, dass die Bienen von den Milben profitieren. In Nestern mit Milbenbefall war kein Pilz zu finden und auch keine Mortalität, und Studien an anderen solitären Bienen hatten bereits gezeigt, dass Pilzbefall eine Hauptursache der Mortalität ist. T. diversipes ist eine weitverbreitete Art. Die Standorte, an denen wir sammelten lagen jedoch alle im Bereich des Atlantischen Regenswalds, dessen hohe Feuchtigkeit dem Pilzwachstum förderlich ist. Da wir in den Nestern mit Milbenbefall keine toten Bienen fanden, ist es möglich, dass Roubikia Milben diese Pilze in Schach halten.

\section{Solitärbiene / Phoresie / Nistfallen / Atlantischer Regenwald / Symbiose}

\section{REFERENCES}

Alves-dos-Santos I., Melo G.A.R., Rozen J.G. (2002) Biology and immature stages of the bee tribe Tetrapediini (Hymenoptera: Apidae), Am. Mus. Novitates 3377, 1-45.

Baker E.W., Roubik D.W., Delfinado-Baker M. (1987) The developmental stages and dimorphic males of Chaetodactylus panamensis, n. sp. (Acari: Chaetodactylidae) associated with solitary bee (Apoidea: Anthophoridae), Int. J. Acarol. 13, 6573.

Biani N.B., Mueller U.G., Wcislo W.T. (2009) Cleaner mites: sanitary mutualism in the miniature ecosystem of neotropical bee bests, Am. Nat. 173, 841847.

Camarotti-de-Lima M.F., Martins C.F. (2005) Biologia de nidificação e aspectos ecológi$\cos$ de Anthodioctes lunatus (Smith) 
(Hymenoptera:Megachilidae, Anthidiini) em área de tabuleiro nordestino, PB. Neotrop. Entomol. 34, 375-380.

Camillo E. (2005) Nesting biology of four Tetrapedia species in trap-nests (Hymenoptera, Apidae, Tetrapediini), Rev. Biol. Trop. 53, 175-186.

Camillo E., Garófalo C.A., Serrano J.C., Mucilo G. (1995) Diversidade e abundância sazonal de abelhas e vespas solitárias em ninhos-armadilhas (Hymenoptera, Apocrita, Aculeata), Rev. Bras. Entomol. 39, 459-470.

Eickwort G.C. (1994) Evolution and life-history patterns of mites associated with bees, in: Houck MA (Ed.), Mites: Ecological and Evolutionary Analyses of Life- History Patterns, New York, Chapman \& Hall, pp. 218-251.

Engel M.S. (2001) A monograph of the Baltic amber bees and evolution of the Apoidea (Hymenoptera), Bull. Am. Mus. Nat. Hist. 259, 1-192.

Fain A. (1966) Notes sur la biologie des acariens du genre Chaetodactylus et en particulier de $C$. osmiae, parasite des abeilles solitaires Osmia rufa et $O$. cornuta en Belgique (Sarcoptiformes: Chaetodactylidae), Bull. Ann. Soc. R. Belge Entomol. 102, 249-261.

Fain A. (1981) Notes on the hypopi of the genus Chaetodactylus Rondani, 1866 (Acari, Chaetodactylidae), Bull. Inst. R. Sci. Nat. Belg. Entomol. 53, 1-9.

Flechtmann C.H.W., Camargo C.A. (1974) Acari associated with stingless bees (Meliponidae, Hymenoptera) from Brazil, in: Piffl E. (Ed.), Proc. 4th Int. Congr. Acarol. Budapest, Académiai Kiadó, pp. 315-319.

Garófalo C.A., Martins C.F., Alves-dos-Santos I. (2004) The Brazilian solitary bee species caught in trap nests, in: International Workshop on solitary bees and their role in pollination, Beberibe, CE. Solitary Bees: conservation, rearing and management for pollination, Fortaleza: Impresa Universitária, pp. 77-84.

Houck M.A., O’Connor B.M. (1991) Ecological and evolutionary significance of phoresy in the Astigmata, Annu. Rev. Entomol. 36, 611-636.

Klimov P.B., O’Connor B.M. (2007) Ancestral area analysis of chaetodactylid mites (Acari: Chaetodactylidae), with description of new early derivative genus and six new species from the Neotropics, Ann. Entomol. Soc. Am. 100, 810829.

Klimov P.B., O’Connor B.M. (2008) Morphology, Evolution, and Host Associations of BeeAssociated Mites of the Family Chaetodactylidae (Acari: Astigmata), with a monographic revision of North American taxa, Miscellaneous Publications, Museum of Zoology, University of Michigan 199, pp. 1-243.

Klimov P.B., O'Connor B.M., Knowles L.L. (2007a) Museum specimens and phylogenies elucidate ecology's role in coevolutionary associations between mites and their bee hosts, Evolution 61, 1368-1379.

Klimov P.B., Vinson S.B., O'Connor B.M. (2007b) Acarinaria in associations of apid bees (Hymenoptera) and chaetodactylid mites (Acari), Invertebr. Syst. 21, 109-136.

Krombein K.V. (1962) Natural history of Plummers Island, Maryland. XVI. Biological notes on Chaetodactylus krombeini Baker, a parasitic mite of the megachilid bee, Osmia (Osmia) lignaria Say (Acarina, Chaetodactylidae), Proc. Biol. Soc. Wash. 75, 237-250.

Menezes C., Coletto-Silva A., Gazeta G.S., Kerr W.E. (2009) Infestation by Pyemotes tritici (Acari, Pyemotidae) causes death of stingless bee colonies (Hymenoptera: Meliponina), Genet. Mol. Res. 8, 630-634.

Michener C.D. (2000) The Bees of the World. Baltimore, The John Hopkins University Press.

Morato E.F. (2001) Biologia e ecologia de Anthodioctes morato Urban (Hymenoptera, Megachilidae, Anthidiini) em matas contínuas e fragmentos na Amazônia Central, Brasil. Rev. Bras. Zool. 18, 729-736.

O'Connor B.M. (1979) Evolutionary origins of astigmatid mites inhabiting stored products, in: Rodriguez J.G. (Ed.), Recent advances in acarology (1), Academic Press, New York, pp. 273-278.

O'Connor B.M. (1993a) The mite community associated with Xylocopa latipes (Hymenoptera: Anthophoridae: Xylocopinae) with description of a new type of acarinarium, Int. J. Acarol. 19, 159166.

O'Connor B.M. (1993b) Generic relationships in the Chaetodactylidae (Acari: Astigmata) with description of a new genus, Acarologia 34, 345-362.

O’Connor B.M., Klompen J.S.H. (1999) Phylogenetic perspectives on mite-insect associations: the evolution of acarinaria, in: Needham G.R., Mitchell R., Horn D.J., Welbourn W.C. (Eds.), Acarology IX, Vol. 2, Symposia. Columbus, Ohio, Ohio Biological Survey, pp. 63-71.

Okabe K., Makino S. (2002) Phoretic mite fauna on the large carpenter bee Xylocopa appendiculata circumvolans (Hymenoptera: Apidae) with descriptions of its acarinaria on both sexes, J. Acarol. Soc. Jpn 11, 73-84.

Oldroyd B.P. (1999) Coevolution while you wait: Varroa jacobsoni, a new parasite of western honeybees, Trends. Ecol. Evol. 14, 312-315.

Park Y.L., Kondo V., White J., West T., McConnell B., McCutcheon T. (2009) Nest-to-nest dispersal of Chaetodactylus krombeini (Acari, Chaetodactylidae) associated with Osmia cornifrons (Hym., Megachilidae), J. Appl. Entomol. 133, 174-180.

Qu D., Maeta Y., Goubara M., Nakatsuka K.J., Kozo J., Kenji K. (2002) Reproductive strategy in 
the two species of cleptoparasitic astigmatid mites, Chaetodactylus nipponicus and Tortonia sp. (Acari: Chaetodactylidae and Suidasiidae), infesting Osmia cornifrons (Hymenoptera: Megachilidae). I. Invasion/infestation patterns and partial use of the host food, Jpn J. Entomol. 5, 121-141.

Roubik D.W. (1987) Notes on the biology of anthophorid bee Tetrapedia and the mite Chaetodactylus panamensis Baker, Roubik and Delfinado- Baker (Acari: Chaetodactylidae), Int. J. Acarol. 13, 75-76.
Schwarz H.H., Huck K. (1997) Phoretic mites use flowers to transfer between foraging bumblebees, Insectes Soc. 44, 303-310.

Trouessart E.L. (1904) Sur la coexistence de deux formes d'Hypopes dans une même espèce, chez la Acariens du genre Trichotarsus,. C. R. Soc. Biol. 56, 234-237.

Vicidomini S. (1996) Biologia di Xylocopa (Xylocopa) violacea (L., 1758) (Hymenoptera: Apidae): interazione con Sennertia (Sennertia) cerambycina (Acari Chaetodactylidae), Boll. Zool. Agr. Bachic. 28, 71-76. 